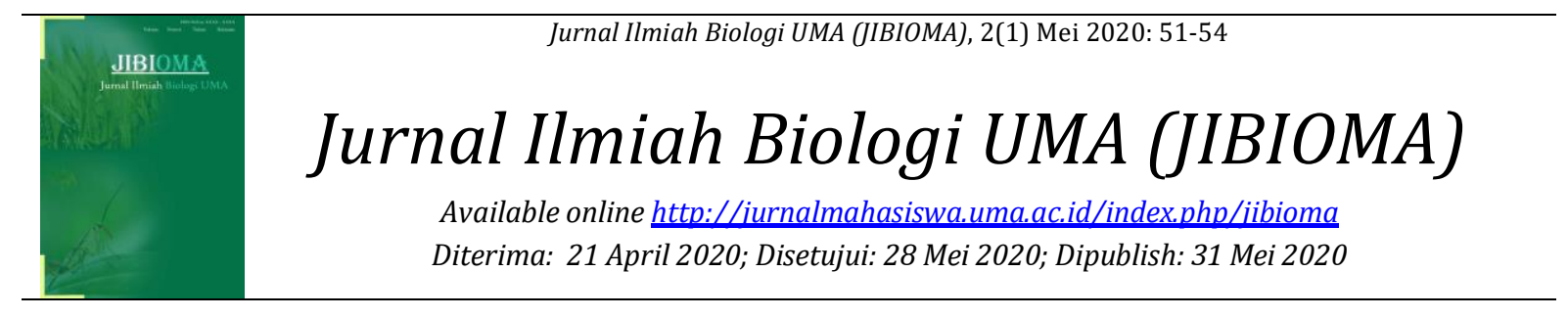

\title{
Uji Cemaran Bakteri pada Bawang Putih Giling yang Dijual di Pasar Tradisional Kecamatan Galang
}

\section{Bacteria Polution Tests in Ground Garlic at Traditional Market Of Galang}

\author{
Listrahot Tondang* , Abdul Karim, dan Sartini
}

Program Studi Biologi, Fakultas Biologi, Universitas Medan Area, Indonesia

\begin{abstract}
Abstrak
Bawang putih merupakan salah satu rempah-rempah atau bumbu dapur yang mempunyai cita rasa dan aroma yang enak dan bawang putih mempunyai banyak manfaat bagi kesehatan. Bumbu yang dibeli dipasar tradisional perlu dijaga kebersihannya untuk menghindari kontaminasi bakteri yang menyebabkan penyakit. Penelitian ini bertujuan untuk mengetahui cemaran bakteri pada bawang putih giling yang dijual dipasar tra disional Kecamatan Galang. Metode penelitian deskriptif untuk melihat jumlah koloni dan karakteristik jenis bakteri yang mengkontaminasi bawang putih yang dijual di pasar tradisional. Hasil uji di laboratorium diperoleh bahwa dari 8 sample terdapat 2 sample tercemar bakteri Klebsiella oxytoca dan 6 sample tercemar bakteri Enterobakter aerogenosa. Kesimpulan yang diperoleh dari penelitian adalah bawang putih giling yang dijual di pasar tradisional Kecamatan Galang masih layak dikonsumsi karena menurut peraturan BPOM no.HK.00.06.1.52.4011 tahun 2009 dan Standart Nasional Indonesia no.7338 tahun 2009 pada herba dan rempah-rempah angka lempeng total tidak melebihi dari ambang batas $1 \mathrm{X} 10^{6} \mathrm{koloni} /$ gram.
\end{abstract}

Kata Kunci: Bakteri, Bawang putih giling, Uji Cemaran

\section{Abstract}

Garlic is one of the spices or spices that has a delicious tastes and aroma and garlic has many health benefits. The ingredients purchased in the traditional market need to be kept clean to avoid bacterial contamination that cause disease. The study aims to determine bacterial contamination of ground garlic sold in the traditional market of Galang. The research method is descriptive to see the number of colonies and the characteristic of the types of bacteria that contaminate onions the white sold in the traditional market in Galang.. The result of laboratory samples obtanied 2 sample contaminated with Klebsiella oxytoca bacteria and 6 sample contaminated with Enterogenous aerogenosa bacteria. Conclutions obtained and the results of this study are ground garlic sample sold in the traditional market of galang distric. It can be concluded that 2 samples were polluted by Klebsiella oxytoca bacteria and 6 samples contaminated with aerogenous Enterobacter bacteria feasible consumption of larvae according to the regultions of BPOM no. HK.00.06.1.53.4011 of 2009 and Indonesian National Standart no.7338 of 2009 on herbs and spices the number of total plates is not greater and the threshold of $1 \times 10^{6}$ colony/gram

Keywords: Bactera; Garlic; Test for contamination

${ }^{*}$ E-mail: listrahottondang2504@gmail.com

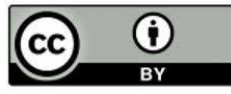


Tondang, L., Karim, A., dan Sartini. Uji Cemaran Bakteri pada Bawang Putih Giling yang Dijual di Pasar Tradisional Kecamatan Galang

\section{PENDAHULUAN}

Indonesia dikenal sebagai negara penghasil rempah-rempah berupa umbi, akar, rimpang, buah biji dan sebagainya, untuk keperluan industri pangan sebagai bumbu masakan yang memberi warna, rasa dan aroma yang sedap pada makanan. Penambahan bumbu bertujuan untuk meningkatkan daya awet suatu masakan (Hambali, 2005). Di pasar terdapat jenis bumbu segar dan bumbu olahan, bumbu segar terdiri dari campuran berbagai rempah dalam keadaan segar yang dihaluskan disebut bumbu giling seperti cabe merah, bawang merah, bawang putih, jahe, lengkuas, kunyit dan lain-lain (Mujianto, 2013).

Bawang putih dengan nama latin Allium sativum termasuk bumbu masak yang paling populer memberikan rasa harum dan khas pada makanan dan banyak manfaat bagi kesehatan terutama menurunkan kolesterol, menurunkan hipertensi, mencegah penyakit jantung, meredakan infeksi, radang, pilek mengatasi rambut rontok (Atmaja. S, 2002 ).

Bumbu yang dijual dipasar tidak dikemas dengan baik dan wadah yang kurang diperhatikan sehingga kwalitas bumbu giling perlu diwaspadai karena pengolahan dan penyimpanan kurang benar sehingga dapat rusak, mudah berubah warna, rasa, bau basi sehingga tidak layak dikonsumsi. Salah satu bumbu giling adalah bawang putih segar yang digiling dengan mesin penggilingan dengan menambah sedikit air dan garam (pengawet alami) selama penyimpanan harus memperhatikan suhu sehingga menghambat pertumbuhan mikroba pembusuk dan kerusakan, juga menghindari kontaminasi fisik seperti debu maupun kontaminasi biologi seperti mikroorganisme (Rosario, 2007). Terlebih lagi melihat kondisi pasar tradisional yang becek dan lembab dapat memperbesar peluang terjadinya kontaminasi oleh bakteri (Rosario, 2007).

Tujuan penelitian adalah untuk mengetahui adanya cemaran bakteri pada bawang putih giling (Alliun sativum) dari dua lokasi pasar tradisional di kecamatan galang. Manfaat penelitian ini diharapkan dapat memberi informasi ilmiah tentang cemaran bakteri pada bawang putih giling dari pasar tradisional di kecamatan Galang.

\section{METODE PENELITIAN}

Penelitian ini dilakukan dengan metode Deskriptif. Sample diambil dari semua penjual bumbu giling berupa bawang putih giling dengan 2 lokasi pasar yaitu pasar 
petumbukan dan pasar galang kota. Untuk mengetahui karakteristik bakteri yang terdapat pada bawang putih giling,Parameter yang diamati adalah jumlah koloni dan jenis bakteri yang mengkontaminasi bawang putih giling

\section{HASIL DAN PEMBAHASAN}

Dari uji bakteriologi yang telah dilakukan terhadap bawang putih giling dari 2 lokasi pasar tradisional di Kecamatan Galang didapatkan hasil sebagai berikut yaitu sebanyak 8 sample bawang putih yang diteliti jumlah populasi bakteri dapat dikatakan memenuhi syarat sesuai standar nasional Indonesia.

Bawang putih sebagai bumbu digunakan hampir dalam setiap makanan dan masakan di indonesia. Pada umumnya pedagang bawang putih giling, dalam pengolahannya tidak mencuci bahan dan peralatannya dengan air bersih, maka diadakan penelitian untuk mengetahui kualitas olahan bawang putih giling yang beredar secara mikrobiologis.

Tabel 1. Jumlah koloni bakteri pada bawang putih giling yang dijual dipasar Kecamatan Galang.

\begin{tabular}{ccc}
\hline Kode Sampel & Jumlah Koloni Bakteri $(\mathrm{CFU} / \mathrm{ml})$ & Keterangan \\
\hline SA1 & $1,00 \times 10^{3}$ & Memenuhi syarat \\
SA2 & $12,0 \times 10^{3}$ & Memenuhi syarat \\
SB1 & $26,0 \times 10^{3}$ & Memenuhi syarat \\
SB2 & $19,0 \times 10^{3}$ & Memenuhi syarat \\
SC1 & $2,46 \times 10^{3}$ & Memenuhi syarat \\
SC2 & $12,0 \times 10^{3}$ & Memenuhi syarat \\
SD1 & $16,0 \times 10^{3}$ & Memenuhi syarat \\
SD2 & $4,00 \times 10^{3}$ & Memenuhi syarat \\
\hline
\end{tabular}

Hasil dari identifikasi bakteri yang mencemari bawang putih giling yang dijual di Pasar Tradisional Kecamatan Galang adalah sebagai berikut pada tabel 2.

Tabel 2. Hasil identifikasi baketri yang mencemari bawang putih

\begin{tabular}{cccc}
\hline \multirow{2}{*}{ Sampel } & Lokasi Pengambilan Sampel & \multicolumn{2}{c}{ Karateristik Bakteri } \\
& G. oxytoca & E. aerogenosa \\
\hline SA2 & Galang & + & + \\
SB1 & Petumbukan & & + \\
SB2 & Galang & & + \\
SC1 & Petumbukan & + & + \\
SC2 & Galang & & + \\
SD1 & Petumbukan & & + \\
SD2 & Galang & & + \\
\hline
\end{tabular}


Tondang, L., Karim, A., dan Sartini. Uji Cemaran Bakteri pada Bawang Putih Giling yang Dijual di Pasar Tradisional Kecamatan Galang

Berdasarkan tabel 2 diatas dapat dilihat bahwa 8 sample bawang putih diantaranya mengandung bakteri Klebsiella oxytoca 25 \%, sedangkan 6 sample tercemar Enterobacter aerogenosa 75 \% bakteri ini merupakan kontaminasi udara bebas yang bersifat non patogen.

\section{SIMPULAN}

Berdasarkan hasil penelitian yang dilakukan disimpulkan bahwa dari 8 sample bawang putih giling yang dijual dipasar tradisional galang terdapat 2 sample yang tercemar bakteri Klebsiella oxytoca dan 6 sample yang tercemar Enterobakter aerogenosa dengan jumlah koloni dibawah ambang batas atau masih memenuhi syarat higiene, jadi bawang putih giling yang dijual dipasar tradisional layak dikonsumsi.

\section{DAFTAR PUSTAKA}

Atmaja. S, 2002 Manfaat bawang putih untuk Kesehatan.Edisi 10. Bumi aksara Jakarta.

Hambali, Erliza, A. Suryani dan M.Rivai. 2005. Membuat Aneka Bumbu Instan Pasta.Jakarta: Penebar Swadaya.

Mujianto. B. Angki P. Siti. R. 2013. Identifikasi Pengawet dan Pewarnaan Berbahaya Pada Bumbu Giling. Jurnal ilmu \& tehnologi kesehatan jilid I Jakarta.

Rosaria, 2007. Studi Keamanan Cabe Giling Dikota Bogor Fakultas Tehnologi Pertanian Institut Pertanian Bogor. 